\title{
Assessment of Toxic Metals in Agricultural Produce
}

\author{
Lokeshappa B. ${ }^{1,2}$, Kandarp Shivpuri ${ }^{1}$, Vivek Tripathi ${ }^{3}$, Anil K. Dikshit ${ }^{1,45, *}$ \\ ${ }^{1}$ Centre for Environmental Science and Engineering, Indian Institute of Technology, Bombay, Powai Mumbai, 400076, India \\ ${ }^{2}$ University BDT College of Engineering, Davangere, Karnataka, 577004, India \\ ${ }^{3}$ Indian Institute of Technology, Bombay, Powai Mumbai, 400076, India \\ ${ }^{4}$ School of Civil and Environmental Engineering, Nanyang Technological University, 639798, Singapore \\ ${ }^{5}$ School of Civil Engineering, Survey and Construction, University of KwaZulu-Natal, Durban, South Africa
}

\begin{abstract}
This study was conducted to analyze the metals in selected vegetables available in Powai area, Mumbai, India. The total 9 samples viz., 5 vegetables, 3 cereals and 1 medicinal plant were collected which are commonly consumed in the locality. These were digested using microwave acid digester with nitric acid and hydrochloric acid and analyzed with the aid of ICP-AES to determine toxic metals. Highly toxic metals such as arsenic and silver were below detectable limit while two of the samples had high mercury and lead content. The results obtained were compared with their permissible levels set by the FAO and WHO and were found to be within safe limits for some metals while concentrations of some of the metals were much greater than permissible limits and were, hence, not safe to consume. It was found that the overall toxic metal accumulation was greater in leafy vegetables viz. spinach, coriander and tubers such as potato.
\end{abstract}

Keywords Agriculture, Heath Hazards, Soil Contamination, Toxic Metals, Vegetables

\section{Introduction}

Toxic elements from wastewater may contaminate agricultural soils, water supplies and environment and hence human food chain. The crops and the vegetables become contaminated either due to soil pollution or due to long exposure to polluted environment[1] and accumulate unfavourable levels of metallic elements within them. The uptake of metals by roots mainly depends on metal and soil characteristics and plant species etc. Thus, metal mobility in plants is very important to determine the effect of soil contamination on plant-metal uptake[2-4].

The metals present in crops can pose serious risk in the consumers in terms of carcinogenesis, mutagenesis and teratogenesis[5]. Excessive content of metals i.e. beyond Maximum Permissible Level(MCL) leads to number of nervous, cardiovascular, renal, neurological impairment as well as bone diseases and several other health disorders [6-8]. Continuous-cumulative behavior as well as the potential toxicity of heavy metals by consumption of contaminated food stuffs leads to a large number of major and minor health disorders in humans.

Vegetables are an essential part of diet and also act as buffering agents for acid generation during digestion[9] and some metals are even important biochemically and psychologically from health point of view as shown in Table 1

* Corresponding author:

dikshit@iitb.ac.in (Anil K. Dikshit)

Published online at http://journal.sapub.org/fph

Copyright (C) 2012 Scientific \& Academic Publishing. All Rights Reserved
Metals viz., cobalt, chromium(III), copper, iron, manganese, molybdenum, selenium and zinc, help in regulating human metabolism. However, manganese acts as an activator and constituent of many enzymes present in humans[13] and so is an essential element for humans[14].

Table 1. Classification of the Metals on basis of Health Hazards[10-12]

\begin{tabular}{|c|c|}
\hline $\begin{array}{c}\text { Nutritionally } \\
\text { essential metals }\end{array}$ & $\begin{array}{c}\text { Cobalt, Chromium, Copper, Iron, Manganese, } \\
\text { Molybdenum, Selenium and Zinc }\end{array}$ \\
\hline $\begin{array}{c}\text { Metals with } \\
\text { possible benefits }\end{array}$ & Boron, Nickel, Silicon and Vanadium \\
\hline $\begin{array}{c}\text { Metals with no } \\
\text { known benefits }\end{array}$ & $\begin{array}{c}\text { Aluminium, Antimony, Arsenic, Barium, Be- } \\
\text { ryllium, Cadmium, Lead, Mercury, Silver and } \\
\text { Strontium }\end{array}$ \\
\hline
\end{tabular}

\subsection{Macro-nutrients}

These metals are required by body in good quantities for proper metabolism and functioning of body organs. These include calcium, magnesium, sodium, potassium and iron.

\subsection{Micro-nutrients}

These metals are required by the body in trace quantities and are essential for maintaining various body functions and metabolic activities. Metals such as silicon, nickel, boron, and vanadium are essential (but toxic at higher levels). These have biological functions in plants and some animals but essentiality for humans and their requirements are under research[13]. The toxicity details of some of the metal causing human disorders are described in the following sections.

\subsubsection{Chromium}


Chromium (VI) compounds are toxics and known human carcinogens, whereas chromium (III) is an essential element. Breathing high levels can cause irritation to the lining of the nose; nose ulcers; running nose; and breathing problems, such as asthma, cough, shortness of breath, or wheezing. Long term exposure can cause damage to liver, kidney, circulatory and nerve disorders, as well as skin irritation[15].

\subsubsection{Copper}

Copper is an essential substance to human life, but its critical doses can cause anemia, acne, adrenal hyperactivity and insufficiency, allergies, hair loss, arthritis, autism, cancer, depression, elevated cholesterol, depression, diabetes, dyslexia, failure to thrive, fatigue, fears, fractures of the bones, headaches, heart attacks, hyperactivity, hypertension, infections, inflammation, kidney and liver dysfunction, panic attacks, strokes, tooth decay and vitamin $\mathrm{C}$ and other vitamin deficiencies[15].

\subsubsection{Selenium}

Selenium is toxic in large amounts, but trace amounts of it are necessary for cellular function. Short-term oral exposure to high concentrations can cause nausea, vomiting, and diarrhea. Major signs of selenosis are hair loss, nail brittleness, and neurological abnormalities. Brief exposures to high levels in air can result in respiratory tract irritation, bronchitis, difficulty breathing, and stomach pains. Longerterm exposure can cause respiratory irritation, bronchial spasms, and coughing[15].

\subsubsection{Zinc}

$\mathrm{Zn}$ is an airborne pollutant, so in general it majorly accumulate to open and above-earth crops; however root crop plants also assimilate great proportion from $\mathrm{Zn}$ contaminated soils[15].

\subsection{Toxic metals}

Arsenic, cadmium, lead, and mercury, and their inorganic compounds, are toxic to human health as well as environment also. Other metals of concern in form of soluble compounds also lead to plausible adverse health effect. The toxicity details of some of the metal caused human disorders are described below.

\subsubsection{Silver}

Exposure to high levels for a long period may result in a condition called argyria, a blue-gray discoloration of the skin and other body tissues, which appears to be a cosmetic problem that may not be otherwise harmful to health. Exposure to high levels of silver in the air can result in breathing problems, lung and throat irritation and stomach pains. Skin contact with silver can cause mild allergic reactions such as rash, swelling, and inflammation[16].

\subsubsection{Aluminum}

While aluminum can be toxic at higher levels, it is considerably less toxic than either mercury or lead. In fact, aluminum is found at easily measurable levels in various biological fluids and tissues. However, at high levels aluminum has the potential to cause a number of health problems such as anaemia and other blood disorders, colic, fatigue, dental caries, dementia dialactica, kidney and liver dysfunctions, neuromuscular disorders, osteomalacia and Parkinson's disease[16].

\subsubsection{Arsenic}

Arsenic is regarded as human carcinogen from extremely low levels of exposure, having no possible beneficial metabolic functions for humans[16]. Its low level exposure cause nausea and vomiting decreased production of RBCs and WBCs, abdominal pain and its long term exposure causes darkening of skin and appearance of small corns on palm soles. Other affect includes abnormal ECG, anorexia, fever, fluid loss, goitre, hair loss, headache, herpes, impaired healing, jaundice, keratosis, kidney and liver damage, muscle spasms, pallor, peripheral neuritis, sore throat, weakness and interferes with the uptake of folic acid[16].

\subsubsection{Barium}

Short term exposure can cause vomiting, abdominal cramps, diarrhoea, difficulties in breathing, increased or decreased blood pressure, numbness around the face, and muscle weakness[16].

\subsubsection{Beryllium}

Studies have shown that high beryllium concentration causes adrenal insufficiency, arthritis, bone-spurs, bursitis, depression, fatigue, osteoporosis and symptoms of slow metabolism[16].

\subsubsection{Cadmium}

Cadmium is very toxic, its long-term exposure to lower levels leads to a build up in the kidneys and possible kidney disease, lung damage, and fragile bones. Hypertension, arthritis, diabetes, anaemia, cancer, cardiovascular disease, cirrhosis, reduced fertility, hypoglycemia, headaches, osteoporosis, kidney disease, and strokes are its some odd long term results[16].

\subsubsection{Mercury}

Mercury combines with other elements to form organic and inorganic mercury compound. Short-term exposure to high levels of metallic mercury vapors may cause lung damage, nausea, vomiting, diarrhoea, increases in blood pressure or heart rate, skin rashes, and eye irritation. Adrenal gland dysfunction, discouragement, dizziness, fatigue, headaches, hearing loss, loss of self-control, memory loss, mood swings, nervousness, numbness and tingling, pain in limbs, rashes, tremors, peripheral vision loss and muscle weakness are its long term effects[16].

\subsubsection{Nickel}

Nickel is known to be responsible for cancer(oral and intestinal), depression, heart attacks, haemorrhages, kidney 
dysfunction, low blood pressure, malaise, muscle tremors and paralysis, nausea, skin problems and vomiting[16].

\subsubsection{Lead}

Lead enters into the body system through air, water and food and cannot be removed by washing fruits and vegetables[17]. It is a serious cumulative body poison, which can affect every organ and system in the body. Exposure to its high levels can severely damage the brain, kidneys and ultimately cause death and long-term exposure result in decreased performance in some tests that measure the functions of the nervous system; weakness in fingers, wrists, or ankles; small increases in blood pressure; and anaemia. Others are abdominal pain, anaemia, arthritis, attention deficit, back problems, blindness, cancer, constipation, convulsions, depression, diabetes, migraine headaches, thyroid imbalances and tooth decay.

Table 2 states the daily intakes for a few metals in the human body. Estimated average requirement (EAR) signifies half the average energy requirement for a nutrient for the healthy individuals. Recommended dietary allowances (RDA) signifies the nutrient requirement of nearly all healthy individuals. Adequate intake (AI) signifies the recommended intake value, in absence of RDA. Tolerable Upper intake level (UL) states the highest intake of nutrient that does not pose any adverse health effect.

Table 2. Dietary Reference Intakes for $\mathrm{Mn}, \mathrm{Fe}, \mathrm{Cu}, \mathrm{Zn}$ and $\mathrm{Se}[18-20]$

\begin{tabular}{|c|c|c|c|c|c|c|c|c|c|}
\hline \multirow{2}{*}{$\begin{array}{c}\text { Metal } \\
(\mathrm{mg} / \mathrm{d})\end{array}$} & $\mathrm{Cu}$ & \multicolumn{2}{|c|}{$\mathrm{Fe}$} & \multicolumn{2}{c|}{ Mn } & \multicolumn{2}{|c|}{ Se } & \multicolumn{2}{|c|}{ Zn } \\
\cline { 2 - 11 } & $\mathrm{M} / \mathrm{F}$ & $\mathrm{M}$ & $\mathrm{F}$ & $\mathrm{M}$ & $\mathrm{F}$ & $\mathrm{M}$ & $\mathrm{F}$ & $\mathrm{M}$ & $\mathrm{F}$ \\
\hline EAR & 0.7 & 6 & 8.1 & - & - & 45 & 45 & 9.4 & 6.8 \\
\hline RDA & 0.9 & 8 & 18 & - & - & 55 & 55 & - & - \\
\hline $\mathrm{AI}$ & - & - & - & 2.3 & 1.8 & - & - & 11 & 8 \\
\hline UL & 10 & 45 & 45 & 11 & 11 & 400 & 400 & 40 & 40 \\
\hline
\end{tabular}

The aim of this study is to detect and determine the concentration of beneficial as well as toxic metals in selected and most commonly-consumable edible vegetables in Powai, Mumbai, India, where municipal and industrial sewage effluents are used due to lack of irrigation water. This causes accumulation of toxic metals in soil and in turn, contaminates the vegetables and other edible crops grown in the area.

\section{Materials and Methods}

\subsection{Samples Collection}

Five vegetables viz. lady's finger (Abelmoschus esculentus), potato (Solanum tuberasum), spinach (Spinacia oleracea), carrot (Daucas carota), and coriander (Coriandrum sativum) were purchased from market near IIT Powai, Mumbai, India. Three daily consumed cereal produces viz. rice (Oryza sativa), mungbean (Vigna radiata) and arhar bean (Cajanus cajan) were procured from DMart Superstore, Powai, Mumbai. One common medicinal leaves viz. tulsi (Ocimum tenuiflorum) was taken from IIT garden.

\subsection{Pretreatment and Washing}

After collection, the samples were brought to the CESE laboratory and processed further for analysis. Edible portions of the samples were used while bruised or rotten portions were removed. The edible portions of the collected vegetable samples were properly washed to eliminate adsorbed dust particles. The samples were then chopped into small pieces using a knife. The vegetables were air-dried for 3 days under hygienic condition to prevent further contamination from in-situ environment and finally, dried in an oven at $105^{\circ} \mathrm{C}$ to constant weight.

\subsection{Grinding of Samples}

Dried samples of the vegetables were ground to powder using a commercial blender and sieved to $150 \mu$. Sieved materials were stored in air tight high density polyethylene containers.

\subsection{Measurement of $\mathrm{pH}$}

All the 9 samples weighing $0.5 \mathrm{~g}$ were mixed with $50 \mathrm{~mL}$ of ultra pure water and kept in orbital shaker at $185 \mathrm{rpm}$ at ambient temperature for 1 hour. The solution $\mathrm{pH}$ was measured using Thermo $\mathrm{pH}$ Meter (Model Orion 3 star, Singapore).

\subsection{Microwave Acid Digestion}

$0.5 \mathrm{~g}$ of each sample were taken into digestion tubes containing $10 \mathrm{~mL}$ of $\mathrm{HNO}_{3}$ and $2.5 \mathrm{~mL}$ of $\mathrm{HCl}(4: 1 \mathrm{v} / \mathrm{v})$. The mixture was digested in a Milestone Microwave Digester (Model MLS 1200, Mega, USA). The operational conditions of the microwave digester are shown in the Table 3.

Table 3. Operation Conditions of Milestone Microwave Digester

\begin{tabular}{|c|c|c|c|}
\hline Steps & Power(W) & Pressure(bars) & Time(minutes) \\
\hline 01 & 250 & 3 & 5 \\
\hline 02 & 400 & 6 & 5 \\
\hline 03 & 500 & 10 & 4 \\
\hline \multicolumn{3}{|c|}{ Ventilation } \\
\hline
\end{tabular}

After digestion was completed, the vessels were allowed to cool to room temperature before removing from microwave unit. The supernatant was decanted from the vessels and solution was made up to $50 \mathrm{~mL}$ by volume with ultra-pure water. Next it was solution was centrifuged at 10000 rpm for 10 min and filtered with $0.2 \mu$ PTFE filter for metal analysis by ICP-AES.

\subsection{Toxic Metals Analysis}

Extract solutions were analyzed with a dilution factor of 1:10. Calibration standards were analysed in the same matrix as the sample and the extractions were carried out in duplicate. The main analytes of interest were $\mathrm{Ca}, \mathrm{Mg}, \mathrm{Mn}, \mathrm{Na}, \mathrm{K}$, $\mathrm{Ag}, \mathrm{Ba}, \mathrm{Bi}, \mathrm{Li}, \mathrm{As}, \mathrm{Fe}, \mathrm{Al}, \mathrm{Si}, \mathrm{Pb}, \mathrm{Cd}, \mathrm{Se}, \mathrm{As}, \mathrm{Zn}, \mathrm{Hg}, \mathrm{Ni}, \mathrm{Cu}$ and $\mathrm{Cr}$. Horriba Joybin Inductively Coupled Plasma-Atomic Emission Spectrophotometer(Model Ultima, France) was 
used for metal analysis(Table 4).

Table 4. ICP-AES Instrumental and Operational Conditions

\begin{tabular}{|c|c|}
\hline Parameters & Value/Type \\
\hline RF generator power & $1.2 \mathrm{~kW}$ \\
\hline RF frequency & $40 \mathrm{MHz}$ \\
\hline Plasma & $12.01 /$ minutes \\
\hline Auxillary & $0.751 /$ minutes \\
\hline Nebulizer type & Glass concentric \\
\hline Integration time & 3 Seconds \\
\hline Replicates & 2 \\
\hline
\end{tabular}

\section{Results and Discussion}

The trends for the metal concentrations in the examined vegetables are summarised below.

Table 5. $\mathrm{pH}$ of Samples

\begin{tabular}{|c|c|c|}
\hline Sample & Designation & Final $\mathrm{pH}$ of solution \\
\hline Potato & PO & 5.68 \\
\hline Spinach & SP & 9.48 \\
\hline Coriander & CO & 6.52 \\
\hline Ladyfinger & LA & 5.97 \\
\hline Carrot & CA & 4.39 \\
\hline Tulsi & TU & 6.32 \\
\hline Rice & RI & 6.64 \\
\hline Mungbean & MB & 6.99 \\
\hline Arharbean & AB & 6.93 \\
\hline
\end{tabular}

The mean concentrations (in $\mu \mathrm{g}$ of metallic element per $\mathrm{g}$ unit of vegetable sample) of metals found in the collected nine samples are shown in Figures 1 and 2.

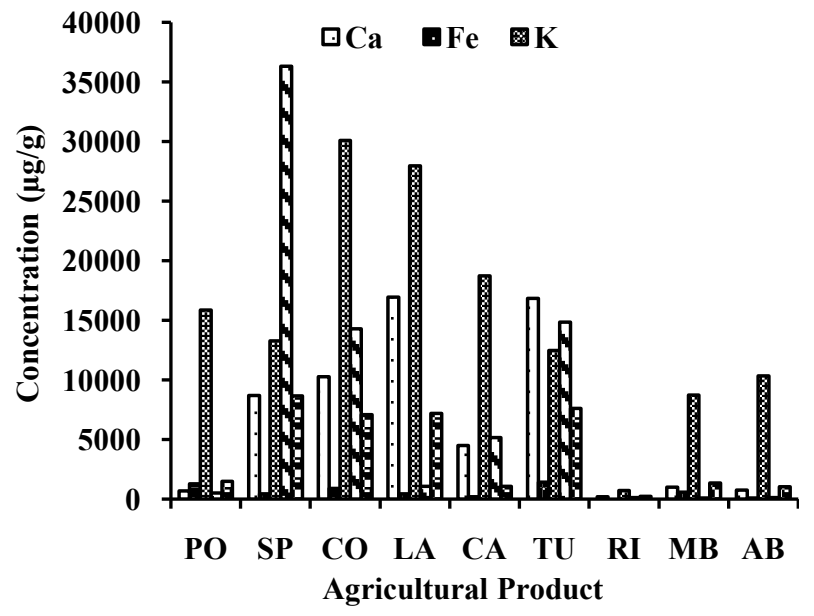

Figure 1. Concentrations of macronutrients in agricultural products

Potassium was abundant in all the samples except rice, while $\mathrm{Na}$ was the second most abundant element which was found in vegetables but absent in $\mathrm{RI}, \mathrm{MB}$ and $\mathrm{AB}$, i.e. in rice and beans. Calcium was present in higher concentrations in green leafy vegetables than rice, potato and beans. Iron was present in small quantities in all samples except rice and arharbean, being high in tulsi, coriander and potato. Table 6 shows relative abundance of various macronutrients in various agricultural samples.
Table 6. Relative Abundance of Macronutrients in Agricultural Products

\begin{tabular}{|c|l|}
\hline $\mathrm{Ca}$ & $\mathrm{LA}>\mathrm{TU}>\mathrm{CO}>\mathrm{SP}>\mathrm{CA}>\mathrm{MB}>\mathrm{AB}>\mathrm{PO}>\mathrm{RI}$ \\
\hline $\mathrm{Fe}$ & $\mathrm{TU}>\mathrm{PO}>\mathrm{CO}>\mathrm{MB}>\mathrm{LA}>\mathrm{SP}>\mathrm{CA}>\mathrm{CO}>\mathrm{RI}$ \\
\hline $\mathrm{K}$ & $\mathrm{CO}>\mathrm{LA}>\mathrm{CA}>\mathrm{PO}>\mathrm{SP}>\mathrm{TU}>\mathrm{AB}>\mathrm{MB}>\mathrm{RI}$ \\
\hline $\mathrm{Mg}$ & $\mathrm{SP}>\mathrm{TU}>\mathrm{LA}>\mathrm{CO}>\mathrm{PO}>\mathrm{MB}>\mathrm{CA}>\mathrm{AB}>\mathrm{RI}$ \\
\hline $\mathrm{Na}$ & $\mathrm{SP}>\mathrm{TU}>\mathrm{CO}>\mathrm{CA}>\mathrm{LA}>\mathrm{PO}>\mathrm{RI}>\mathrm{AB}>\mathrm{MB}$ \\
\hline
\end{tabular}

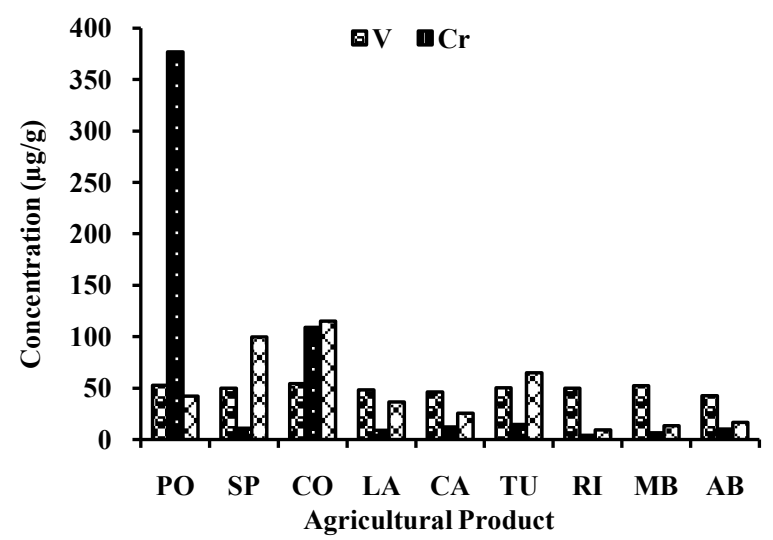

(a)

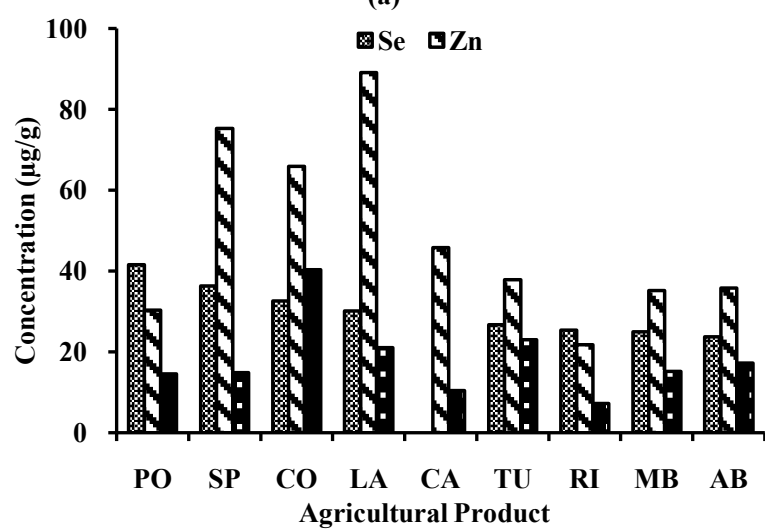

(b)

Figure 2. Concentrations of micronutrients in agricultural products

As can be seen from Figure 2 that vanadium was present in moderate concentrations in all the samples, while manganese was present in slightly higher concentrations in green leafy vegetables and potato and moderate concentrations in other samples. Chromium was present in high concentration in potato, moderate concentrations in coriander and lower concentrations in other samples. Zinc was present in higher concentrations in ladyfinger and spinach, while in moderate concentrations in other samples. Selenium was present in all samples in moderate concentrations except carrot. Copper was in moderate concentrations in coriander, tulsi and ladyfinger and lower concentrations in other samples. Table 7 shows relative abundance of micronutrients in analysed samples.

Table 7. Relative Abundance of Micronutrients in Agricultural Products

\begin{tabular}{|c|l|}
\hline $\mathrm{Cr}$ & $\mathrm{PO}>\mathrm{CO}>\mathrm{TU}>\mathrm{CA}>\mathrm{SP}>\mathrm{AB}>\mathrm{LA}>\mathrm{MB}>\mathrm{RI}$ \\
\hline $\mathrm{Cu}$ & $\mathrm{CO}>\mathrm{TU}>\mathrm{LA}>\mathrm{AB}>\mathrm{MB}>\mathrm{SP}>\mathrm{PO}>\mathrm{CA}>\mathrm{RI}$ \\
\hline $\mathrm{Mn}$ & $\mathrm{CO}>\mathrm{SP}>\mathrm{TU}>\mathrm{PO}>\mathrm{LA}>\mathrm{CA}>\mathrm{AB}>\mathrm{MB}>\mathrm{RI}$ \\
\hline $\mathrm{Se}$ & $\mathrm{PO}>\mathrm{SP}>\mathrm{CO}>\mathrm{LA}>\mathrm{TU}>\mathrm{RI}>\mathrm{MB}>\mathrm{AB}>\mathrm{CA}$ \\
\hline $\mathrm{V}$ & $\mathrm{CO}>\mathrm{PO}>\mathrm{MB}>\mathrm{TU}>\mathrm{SP}>\mathrm{RI}>\mathrm{LA}>\mathrm{CA}>\mathrm{AB}$ \\
\hline $\mathrm{Zn}$ & $\mathrm{LA}>\mathrm{SP}>\mathrm{CO}>\mathrm{CA}>\mathrm{TU}>\mathrm{AB}>\mathrm{MB}>\mathrm{PO}>\mathrm{RI}$ \\
\hline
\end{tabular}




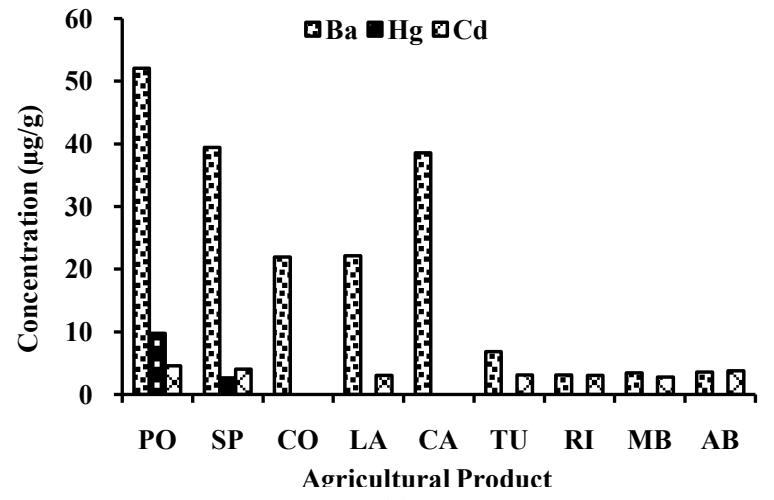

(a)

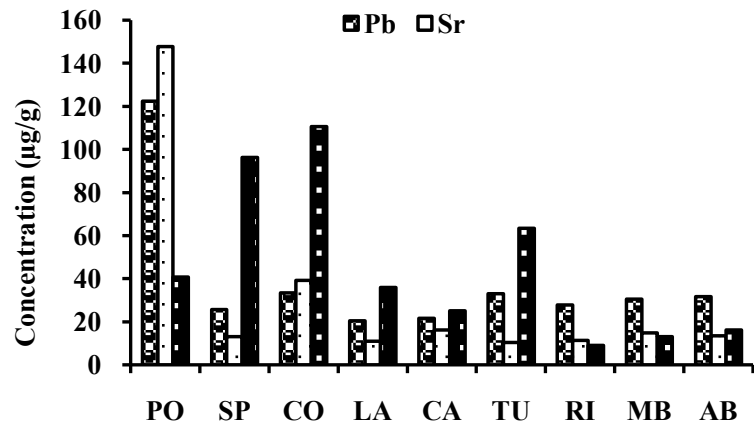

Agricultural Product

(b)

Figure 3. Concentrations of toxic elements in agricultural products

Barium was present in moderate concentrations in potato, spinach and carrot and in lower concentrations in others(Figure 3). Cadmium was present in small concentrations in all samples except coriander and carrot. Mercury was present in small concentrations in potato and spinach and was below detectable limits in all other samples. Lead and strontium were in high concentrations in potato. Lead was in lower concentrations in other samples. Aluminium was in high concentration in spinach and coriander and in moderate concentrations in tulsi, potato and ladyfinger and lower in other samples. Thus, coriander and spinach were 2 vegetables(leafy) showing more metal accumulation, while Bi was showing a concentration of $46 \mu \mathrm{g} / \mathrm{g}$ in LA while it was BDL in all other samples(Table 8).

Table 8. Relative Abundance of Toxic Metals in Agricultural Products

\begin{tabular}{|c|c|}
\hline $\mathrm{Al}$ & $\mathrm{CO}>\mathrm{SP}>\mathrm{TU}>\mathrm{PO}>\mathrm{LA}>\mathrm{CA}>\mathrm{AB}>\mathrm{MB}>\mathrm{RI}$ \\
\hline $\mathrm{Ba}$ & $\mathrm{PO}>\mathrm{SP}>\mathrm{CA}>\mathrm{LA}>\mathrm{CO}>\mathrm{TU}>\mathrm{AB}>\mathrm{MB}>\mathrm{RI}$ \\
\hline $\mathrm{Bi}$ & $\mathrm{LA} /$ Remaining in $\mathrm{BDL}$ \\
\hline $\mathrm{Cd}$ & $\mathrm{PO}>\mathrm{SP}>\mathrm{AB}>\mathrm{TU}>\mathrm{RI} \approx \mathrm{LA}>\mathrm{MB} /$ Remaining in BDL \\
\hline $\mathrm{Hg}$ & $\mathrm{PO}>\mathrm{SP} /$ Remaining in $\mathrm{BDL}$ \\
\hline $\mathrm{Pb}$ & $\mathrm{PO}>\mathrm{CO}>\mathrm{TU}>\mathrm{AB}>\mathrm{MB}>\mathrm{RI}>\mathrm{SP}>\mathrm{CA}>\mathrm{LA}$ \\
\hline $\mathrm{Sr}$ & $\mathrm{PO}>\mathrm{CO}>\mathrm{CA}>\mathrm{MB}>\mathrm{AB}>\mathrm{SP}>\mathrm{RI}>\mathrm{LA}>\mathrm{TU}$ \\
\hline
\end{tabular}

It can be seen that concentrations for $\mathrm{Cd}, \mathrm{Cr}, \mathrm{pb}$, Se and $\mathrm{Zn}$ were above the permissible limits tabulated in Table 9.

Table 9. Permissible Limits of some Metals in Vegetables[21,22]

\begin{tabular}{|c|c|c|c|c|c|c|}
\hline Metals & $\mathrm{Cd}$ & $\mathrm{Cu}$ & $\mathrm{Cr}$ & $\mathrm{Pb}$ & $\mathrm{Sr}$ & $\mathrm{Zn}$ \\
\hline PermissibleLimits $(\mu \mathrm{g} / \mathrm{g})$ & 0.2 & 73.3 & 2.3 & 0.3 & - & 9.4 \\
\hline
\end{tabular}

The metal accumulation was observed to be highest in coriander, followed by spinach, tulsi and potato. These samples had higher concentrations of almost all metals evaluated in the study. This can be seen in the relative abundance results tabulated from Table 6 through Table 8 . Vanadium was present in all the samples in moderate to high concentrations (30-40 $\mu \mathrm{g} / \mathrm{g}$ or higher), while zinc and manganese were present in moderate to high concentrations in all the vegetables. Rice and beans had lower concentrations of all the metals studied with exception of vanadium which was present in rice and beans in moderately high concentrations and mungbean showed higher concentrations of cadmium.

The macronutrients, i.e., $\mathrm{Ca}, \mathrm{Mg}, \mathrm{K}, \mathrm{Na}$ and $\mathrm{Fe}$ were present in high concentrations in tulsi, coriander and ladyfinger and were absent in rice and beans. Tulsi had the least number of toxic metals in high concentration and contained most of the macronutrients in optimum to high concentrations, while coriander had micronutrients and toxic metals along with macronutrients in optimum to high concentrations.

The following Table 10 enlists the metals which were below detectable limits in all the samples.

Table 10. Conc. of Metals below Detection Limits (BDL) in Vegetables Cultivated in and around Powai

\begin{tabular}{|c|c|c|c|c|c|c|c|}
\hline $\begin{array}{c}\text { Sam- } \\
\text { ple }\end{array}$ & $\begin{array}{c}\text { As } \\
(\mu \mathrm{g} / \mathrm{g})\end{array}$ & $\begin{array}{c}\mathrm{Li} \\
(\mu \mathrm{g} / \mathrm{g})\end{array}$ & $\begin{array}{c}\mathrm{B} \\
(\mu \mathrm{g} / \mathrm{g})\end{array}$ & $\begin{array}{c}\mathrm{Si} \\
(\mu \mathrm{g} / \mathrm{g})\end{array}$ & $\begin{array}{c}\mathrm{Ni} \\
(\mu \mathrm{g} / \mathrm{g})\end{array}$ & $\begin{array}{c}\mathrm{Ag} \\
(\mu \mathrm{g} / \mathrm{g})\end{array}$ & $\begin{array}{c}\mathrm{Co} \\
(\mu \mathrm{g} / \mathrm{g})\end{array}$ \\
\hline $\mathrm{PO}$ & $\mathrm{BDL}$ & $\mathrm{BDL}$ & $\mathrm{BDL}$ & $\mathrm{BDL}$ & $\mathrm{BDL}$ & $\mathrm{BDL}$ & $\mathrm{BDL}$ \\
\hline $\mathrm{SP}$ & $\mathrm{BDL}$ & $\mathrm{BDL}$ & $\mathrm{BDL}$ & $\mathrm{BDL}$ & $\mathrm{BDL}$ & $\mathrm{BDL}$ & $\mathrm{BDL}$ \\
\hline $\mathrm{CO}$ & $\mathrm{BDL}$ & $\mathrm{BDL}$ & $\mathrm{BDL}$ & $\mathrm{BDL}$ & $\mathrm{BDL}$ & $\mathrm{BDL}$ & $\mathrm{BDL}$ \\
\hline $\mathrm{LA}$ & $\mathrm{BDL}$ & $\mathrm{BDL}$ & $\mathrm{BDL}$ & $\mathrm{BDL}$ & $\mathrm{BDL}$ & $\mathrm{BDL}$ & $\mathrm{BDL}$ \\
\hline $\mathrm{CA}$ & $\mathrm{BDL}$ & $\mathrm{BDL}$ & $\mathrm{BDL}$ & $\mathrm{BDL}$ & $\mathrm{BDL}$ & $\mathrm{BDL}$ & $\mathrm{BDL}$ \\
\hline $\mathrm{TU}$ & $\mathrm{BDL}$ & $\mathrm{BDL}$ & $\mathrm{BDL}$ & $\mathrm{BDL}$ & $\mathrm{BDL}$ & $\mathrm{BDL}$ & $\mathrm{BDL}$ \\
\hline $\mathrm{RI}$ & $\mathrm{BDL}$ & $\mathrm{BDL}$ & $\mathrm{BDL}$ & $\mathrm{BDL}$ & $\mathrm{BDL}$ & $\mathrm{BDL}$ & $\mathrm{BDL}$ \\
\hline $\mathrm{MB}$ & $\mathrm{BDL}$ & $\mathrm{BDL}$ & $\mathrm{BDL}$ & $\mathrm{BDL}$ & $\mathrm{BDL}$ & $\mathrm{BDL}$ & $\mathrm{BDL}$ \\
\hline $\mathrm{AB}$ & $\mathrm{BDL}$ & $\mathrm{BDL}$ & $\mathrm{BDL}$ & $\mathrm{BDL}$ & $\mathrm{BDL}$ & $\mathrm{BDL}$ & $\mathrm{BDL}$ \\
\hline
\end{tabular}

\section{Summary and Conclusions}

The toxicity of the metals in agricultural products depends upon relative level of exposure of crops to the contaminated soils as well as the deposition of toxic elements in the polluted air by sedimentation. Different metals show the toxicity at different concentrations and can be potentially toxic at sufficiently high concentrations. However, certain metals exhibit toxic effects even at relatively low concentrations. Metal toxicity depends on the element, its chemical form and its oxidation state. However, the mechanisms responsible for toxicity are not studied in this paper.

The results show that metal accumulation was a severe phenomenon occurring in vegetables and crop food stuffs consumed in and around Powai area in Mumbai. Concentrations of $\mathrm{Cd}, \mathrm{Cr}, \mathrm{Pb}, \mathrm{Se}$ and $\mathrm{Zn}$ were above permissible limits and the agricultural products like potato, spinach and coriander were exhibiting high accumulation of most of these metals. The consumption at both acute(high exposure level) or chronic(low exposure over long periods) levels of these vegetables can lead to adverse health effects. Lady finger and 
tulsi had relative abundance of macronutrients and so could be consumed after proper washing.

Thus, toxic metal accumulation in vegetables detected was severe and has potential to cause health risk in and around Powai. It is suggested that regular monitoring should be enforced as these metal accumulation in vegetables and food stuff can be toxic to consumers when they are present in excess or cause deficiency diseases when present in deficient quantities than required by our body.

\section{ACKNOWLEDGEMENTS}

The authors are thankful to the Centre for Environmental Science and Engineering, IIT Bombay for providing facilities for this research work. Vivek Tripathi is grateful to Kishore Vaigyanik Protsahan Yojana(KVPY) for providing the opportunity to do this research and Industrial Research and Consultancy Cell, IIT Bombay for providing him the financial support.

\section{REFERENCES}

[1] Sobukola O.P., and Dairo O.U., 2007, Modeling drying kinetics of fever leaves (Ocimum viride) in a convective hot air dryer., Niger. Food J., 25(1), 145-153

[2] Luo, Y., and Rimmer D.L., 1995, Zinc-Copper interaction affecting plant growth on a metal contaminated soil., Environ Pollution., 88, 79-83

[3] Sresty, T.V.S., and Rao, K.V.M., 1999, Ultra structural alteration in response to zinc and nickel stress in the root cells of Pigeon pea., Journal of Environmental and Experimental Botany, 41, 3-13

[4] Sekhar, K.C., Supriya, K.R., Kamala, C.T., Chary, N.S., Rao, T.N., and Anjaneyulu, Y., 2001, Speciation, accumulation of heavy metals in vegetation grown on sludge amended soils and their transfer to human food chain-a case study, Toxicological and Environmental Chemistry, 82, 33-34

[5] Radwan, M.A., and Salama, A.K., 2006, Market basket survey for some heavy metals in Egyptian fruits and vegetables., Food Chem Toxicol; 44, 1273-1278

[6] WHO, Cadmium Environmental Health Criteria, Geneva: World Health Organization, 1992: 134

[7] Steenland, K, and Boffetta P., 2000, Lead and cancer in humans: where are we now?., Am J Ind Med, 38, 295-299

[8] Jarup L., 2003, Hazards of heavy metal contamination., $\mathrm{Br}$
Med Bull, 68, 167-82

[9] Maleki, and Zarasvand., 2008, Heavy metals in selected edible vegetables and estimation of their daily intake in Sanandaj, Iran., Southeast Asian J Trop Med Public Health

[10] Prentice A., 1993, Does mild zinc deficiency contribute to poor growth performance?., Nutr Rev, 51, 268-270

[11] Linder C., and Azam M.H., 1996, Copper biochemistry and molecular biology., Am Journal of Clinic Nutrient., 63, 791-796

[12] Goyer, R., Golub, M., Choudhury, H., Hughes, M., Kenyon, E., and Stifelman, M., 2004, Issue paper on the human health effects of metal

[13] "Dietary reference intakes for Vitamin A, Vitamin K, arsenic, boron, chromium, copper, iodine, iron, manganese, molybdenum, nickel, silicon, vanadium, and zinc," NAS/IOM(National Academy of Sciences/Institute of Medicine), Food and Nutrition Board, Institute of Medicine, Washington, DC, 2003

[14] Goyer, R.A., Clarkson T.M.(2001) Toxic effects of metals, In: Klaassen, C.D., ed Casarett \& Doull's toxicology. New York: McGraw-Hill, pp. 811-868

[15] H. Kabata and A. Pendias, Trace Elements in Soil and Plants, 2nd Edn., Boca Boca Raton FL, USA, 365, Lewis, 1993

[16] Arsenic in drinking water. NAS/NRC(National Academy of Sciences/National Research Council).Washington, DC. pp. 251-257(1999)

[17] Divrikli, U., Saracoglu, S., Soylak, M., Elci, L., 2003, Determination of trace heavy metal contents of green vegetables samples from Kayseri-Turkey by flame atomic absorption spectrometry., Fresenius Environ. Bull., 12, 1123-1125

[18] Fraga, C.G., 2005, Relevance, essentiality and toxicity of trace elements in human health-Review, Molecular Aspect of Medicines, 26, 235-244

[19] "Dietary Reference Intakes for Vitamin C, Vitamin E, Selenium, and Carotenoids," Food and Nutrition Board, National Academy Press, Washington, DC, 2000

[20] "Dietary Reference Intakes for Vitamin A, Vitamin K, Arsenic, Boron, Chromium, Copper, Iodine, Iron, Manganese, Molybdenum, Nickel, Silicon, Vanadium, and Zinc," Food and Nutrition Board, National Academy Press, Washington, DC, 2001

[21] Chary, N.S., Kamala, N.C., and Raj, D.S.S., 2000, Assessing risk of heavy metals from consuming food grown on sewage irrigated soils and food chain transfer., Ecotoxicology and Environmental Safety, 69(3), 513-524

[22] Codex General Standard for Contaminants and Toxins in Food and Feed, Codex Stan 193, 1995 